\title{
Happy Schools: Perspectives and Matters of Organization-Pedagogy in School's Building and Development
}

\author{
Phạm Minh Giản ${ }^{1}$, Đặng Quốc Bảo², Tăng Thái Thụy Ngân Tâm ${ }^{1}$ \& Phạm Văn Tặc ${ }^{1}$ \\ ${ }^{1}$ Dong Thap University, Vietnam \\ ${ }^{2}$ Institute of Vietnamese Intellectual, Vietnam \\ Correspondence: Phạm Minh Giản, Dong Thap University, Vietnam. E-mail: pmgian@dthu.edu.vn \\ Received: January 30, 2021 \\ Accepted: March 17, $2021 \quad$ Online Published: May 17, 2021 \\ doi:10.5539/ies.v14n6p92 \\ URL: https://doi.org/10.5539/ies.v14n6p92
}

\begin{abstract}
Building "happy schools" has been one of the key concerns by many countries in recent years with an aim to create a friendly, safe, and happy teaching and learning environment so that teachers and students can have more motivation in improving their teaching and learning achievements, thus bringing forth more happiness to the involved individuals and organizations. The article introduces the concept of a "happy school", outlined the perspectives on building happy schools by the world and Vietnamese political, cultural leaders, educational researchers as well as organizations so that they can be applied in the process of educational innovation. Thereby, the authors identify the key elements and criteria for such a "happy school" model, clarify the roles of the schools' headmasters as well as summarize a set of ten messages for a happy school to prepare under the current situation of school innovation.
\end{abstract}

Keywords: happiness, happy school, conception, criteria, application, organization-pedagogy

\section{Introduction}

\subsection{The Role of Happy Schools}

The physical core of any country's education is its schools. The schools are the foreheads that guide the wisdom of the entire people in communities, and are the hearts of the communities, the hands to lead the communities to living aims of humanity and creativity.

Building happy schools plays an important role in improving the quality of teaching and learning as well as in contributing to the development of current national education. A happy school simply means a school offering its students a happy learning environment, enabling them to feel happy and excited with going to school, with receiving knowledge from their teachers. Such schools may help increase students' motivation, eagerness, creativity for higher academic performance, which altogether generate their teachers' enthusiasm and readiness for their teaching work as a result.

\subsection{The Practical and Theoretical Meanings of the Study for Happy Schools}

In term of theoretical meanings, research results on happy schools will help leaders, educational managers, and research experts have scientific background to propose models, criteria, and contents and orientation for building safe, healthy, high-quality and effective schools to create happiness in schools, contributing to the sustainable development of societies and nations.

Research results on happy schools will surely enable leaders, education managers, educational practicers inside and outside the schools to have a theoretical and scientific basis in their practical application in building high-quality and effective schools; creating a safe, peaceful and truly happy environment in which teachers and students are the main force of the school and a driving force for the schools, communities, and countries in the world.

\subsection{Stress and Pressure Arising in the Current School Environment}

In the relationship between happiness and quality of education, UNESCO launched a project on happy schools (2014) to promote the students' health and happiness. "The United Arab Emirates has appointed a Minister of Happiness. Many schools in the UK have started to teach mental health and mindfulness programs to students ... However, the fact that students come to school with many learning related problems such as stress, pressure ... is 
unavoidable. For example, Korea is praised for its students' high academic achievements and PISA scores, but its students are the least unhappy ones in the world due partly to exam pressure and school stress ..." (Pham \& Bui, 2020)

Nowadays, several precious educational traditions have been tainted by a few teachers and students who fail to conduct human and genuine behavior. These teachers, due partly to the influence of the market economy, have become misbehaviors: bullying, intimidating students or committing violent actions to students at their disappointment with students' study results or behavior; some have even implemented educationally commercialized activities like forcing students to take extra classes. Reality has recorded that a male teacher punished students by giving them a drink of water derived from the blackboard sponge. One high school female teacher tortured her students with her emotionless silence by talking nothing in her math class during the whole semester but by "writing everything on the board" as she meant to give punishment to her students. Worse still, some teachers have "hit their students by kicks and fists". On the other hand, there have also several sad educational phenomena among students' behavior, who showed laziness, deception, and indifference to the values of "truth - goodness - beauty" to life.

These phenomena, not quite popular in schools though, have made the whole society worried and concerned because teachers/students' inadequate behavior of any kinds will bring pain to the society as a consequence. In general, a happy school must be a place where students and teachers can learn and teach in a safe, friendly environment, where all the involved parties love, sympathize and share with each other. Every day of going to school is filled with joy for students and teachers.

With the intention of contributing to the clarification of the above contents, the authors conducted the research paper "Happy schools: perspectives and matters of organization and pedagogy in their building and development".

\section{Methodology}

Synthesizing documents, theories and experiences by cultural and political leaders, educational researchers... is used in this article. Useful conclusions are also drawn from the responses by educational managers, teachers, and students in our interviews.

\subsection{Synthesis and Analysis of Documents}

The authors synthesized and analyzed the achievements by the previous researchers, who have provided initial ideas about perspectives, organization and pedagogy activities for a model of "happy schools" in the context of education innovation, including (i) Confucius with "Hanh Dan" being considered the first happy school of mankind, (ii) Raja Roy Singh - a teacher, (iii) Nguyen Khac Vien with the model of personality development, and (iv) virtue teachings by Abraham Lincoln, Albert Einstein, Ho Chi Minh, Nelson Mandela, Dalai Lama in term of the functions, responsibilities of the school, the roles of the teachers and the teacher-student relationship in teaching and educating activities, (v) Pham Van Dong for the constructive ideas regarding to "a happy school", (vi) Nguyen Canh Toan and Nguyen Khac Vien on the issue of "organization-pedagogy" for school's sustainable development and (vii) set of criteria for a happy school by UNESCO and (viii) sectoral documents on the reality of school violence and students' stress and pressure in Vietnam setting context.

\subsection{Interviews}

In addition to the above-mentioned research method, one more instrument was used for data collection by conducting interviews with educational managers, university students, school students (secondary and high schools) who gave answers, ideas to the questions about their understandings, feelings of happiness, happy schools, componential elements, criteria for a happy school as well as measures to build happy schools.

\section{The Rationale}

\subsection{The Concept of Happiness and Happy Schools}

The concept of happiness is defined by different ways. Aristotle once said "Happiness is the meaning and the purpose of life, the whole aim and end of human existence" (Crip, 2000). Osho, an Indian scholar (1931-1990), who is admired by world philosophers, stated in his work "Happiness That Comes From Within" that "Happiness does not mean success, nor does hope, or try to get money, benefits, reputation. Happiness is when we do something consciously, not with a will" (Osho, 2019). Those who follow Maslow's hierarchy of needs" would believe that "Happiness is a non-human category" that can be met and mastered according to the following pyramid (i) physiological needs, (ii) safety needs, (iii) love and belonging needs, (iv) esteem needs and (v) self-actualization needs in their hierarchy. Additionally, happiness is "a state of happiness because of feeling that 
the will has been obtained" (Nguyen, et al., 1999). It is even more subtle to for the matter to apply in school because there are both students and teachers there. For students to be happy, teachers must be the first to achieve happiness. For teachers who have a heart of "all for their beloved students", even if they must work hard, still see themselves as happy as their students make progress.

During the history of educational development, there have been many school models, including positive school model, effective school model, smart school model, excellent school model, friendly school model, and happy school model. These school models share a common goal which is developing towards the formation and development of students' qualities and capacities, promoting creativity in teaching, building a safe, healthy, stimulating educational environment, stimulating the development of teachers and students' stage of being merry and happy. The model of happy school has been proposed by UNESCO since 2014, basing on 3 Ps with the first $\mathrm{P}$ being People. In order to have a happy school, it is necessary to focus on building human values and standards of positive behavior between teachers and learners, between teachers and teachers, between teachers and school administrators, between teachers and parents. The second P is Process (System): processes, policies and activities should be scientifically and reasonably designed to operate the school. The third P is Place in which the school's physical and cultural environment is safe and friendly.

Vietnam is implementing a campaign to build happy schools to inherit the positive aspects and get rid of what has not been done in the previous campaign of "Build friendly schools, build new schools (Viet Nam Escuela Nueva)". In 2019, the Ministry of Education and Training and the Vietnam Education Trade Union launched the campaign of "Implementing a plan to improve the teachers' capacity, pedagogical behavior, and ethics for a happy school". After that, all the schools across the country organized activities including scientific conferences, school dialogues aiming at clarifying the contents of the campaign such as definitions of a happy school, the criteria for building a happy school, specific measures to building a happy school, the roles of students, teachers and managers in this cause.

There are many perspectives on happy schools. A happy school is a place where students feel happy. They not only absorb knowledge, but also have fun, entertain themselves, freely express their thinking, personal abilities, and creative skills in accordance with their psycho-physiological age. In such a school model, students are cared for, protected, and are free from any school violence forms; students and teachers have a chance to get closer; students are respected by teachers for their differences; teachers understand, share difficulties and support students in all aspects; there will be no longer any pressure on grades, academic achievement, and formal emulation movements. Additionally, a happy school is made up of the standardized behaviors of teachers who have pure morality, love their jobs, and are committed. Teachers are proactive in self-study, self-practice and supplement of professional skills to improve pedagogical behavioral capacity towards the complete stop of teachers' ethical violations and non-pedagogical behaviors; teachers must turn career difficulties and challenges into opportunities to assert their own qualities and abilities by the parents, colleagues and students. To sum up, a happy school is a school where the managers, the teachers, and assistant employees always feel happy working in it; students are always happy in every class and every activity. It is proposed that happy schools are places where there exist happy classes, happy lessons, and happy learning time.

There have been many studies on the factors of a happy school. According to Talebzadeh and Samkan (2011) who cited the research results by Sadeghi (2006), there are 17 factors that create newness in happy schools as follows: (i) reducing courses, (ii) improving life skills, (iii) performing fun activities, (iv) disseminating appropriate information, (v) beautifying the environment, (vi) nurturing students' talents and curiosity, (vii) catering welfare works and school equipment, (vii) employing qualified teachers, (ix) preventing all discrimination and encouraging persuasion, (x) making appropriate educational plans to better understand the principles, (xi) providing laboratory and seminar equipment, (xii) students participating in activities, (xiii) creating a healthy environment, (xiv) promoting students' creativity and innovation, (xv) performing team work, (xvi) keeping the question exams within the course contents, (xvii) reducing students' worries and anxieties. Furthermore, Talebzadeh and Samkan (2011), cited Wolk as proposing that by focusing on the following important principles, there can be more happiness when students come to school and they find more happiness by working in school: (i) finding happiness in learning, (ii) offering different choices for students, (iii) allowing students to create anything, (iv) giving students rights to present their ideas (v) setting time for work, (vi) creating an attractive school space, (vii) allowing students to experience, (viii) reading good books, (xix) taking classes on sports and painting, (x) making a change in assessment, (xi) creating fun for the student groups.

A UNESCO proposed happy school must have 22 criteria and the criteria are divided into 3 groups. The group of human criteria includes (i) friendship and relationship in the school community, (ii) quality and positive attitude of teachers, (iii) respect for diversity and difference, (iv) positive and collaborative values/practices, (v) teacher's 
working conditions and well-being, (vi) teachers' skills and competencies. the group relating to operational process include (vii) reasonable and fair workload, (viii) teamwork and cooperative spirit, (ix) funny and interesting teaching and learning approaches, (x) students' freedom, creativity and participation, (xi) a sense of attained achievement and results, (xii) extracurricular activities and school events, (xiii) students and teachers studying together, (xiv) useful, relevant and engaging learning contents, (xv) mental health and stress management. The criteria for learning environment (with 7 criteria) are (xvi) warm and friendly learning environment, (xvii) safe and non-bullying environment, (xvii) open-air and green playing and studying spaces, (xix) school managers' vision and school leadership, (xx) positive discipline, (xxi) excellent health, hygiene and nutrition, (xxii) democratic school management. The educational development process is also the process of developing perceptions, conceptions, attitudes, models of schools, and the practice of building a happy school.

\subsection{The World Perspectives on Happy Schools}

The first human being's happy school to be mentioned here is that of Confucius (551-479), a Chinese philosopher and teacher in the ancient time. Confucius has been known as "vạn thế sư biểu" (a model teacher of all times) by many Eastern countries for his great teachings and thoughts. It is recorded in ancient books that Confucius went to Qufu forest and sat under an old Malahar almond tree on a hill named Hanban. As Confucius was playing and singing, he enlightened his disciples (followers) of the Six Arts. His followers played and sang along with him and bore in their minds what the teacher conveyed about the "self-improvement - behavior", and then they were encouraged with ambition to contribute their work for the country's prosperity and peace. This institution was operated by the teaching objectives: "uneducated - unreasonable", with the teaching content being a set of five values: "humanity - faithfulness - courtousness - intellect - prestige", and the teaching methods being: "scholarly in study - profound in enquiring - deep in thinking - cohesive in comparing and contrasting involved in acting."

The second person to mention the happiness in schools is Abraham Lincoln $(1809-1865)$, one of the greatest US presidents, who sent the principal where his son studied a letter that was worth cogitating. In the letter, he recommended his son to the teacher with all faith and hopes that the teacher would teach his son good and right things. The letter ended with a humane message: "Teacher, I know this is a big order. However, please try your best. If so, then my son is indeed a happy and lucky boy". His message implies that students will be happy when they are in a happy school with good teachers.

Following Abraham Lincoln is Elbert Einstein (1879 - 1955), who is considered the "genius" of mankind thanks to his scientific discoveries, especially the Theory of Relativity. In the field of education, he had profound and meaningful virtue teachings whose meanings remain unchanged in today's life. In an essay, he wrote:
“...It is not enough to teach people a discipline. By doing so, he may become a working machine but cannot become a person of full personalities. It is important that he is taught to have a vivid sense of what is worth striving in life. He must be taught to have a vivid awareness of what is beautiful and what is good.
...These treasures are passed on to the younger generation through direct contact with the teacher, not - or not primarily - through books. That is the first thing that creates culture and preserves culture. I always think about it when I recommend that "humanities" subjects such as Greek literature and art ...) are important, not specialized knowledge and dry lessons in the field of history and philosophy.

...In addition, one more element belonging to the nature of a valuable education is that independent critical thinking must be developed in young people - a development seriously threatened by cramming (in score-based teaching systems). Cramming education inevitably leads to superficiality and culture damage. It is required in teaching that students will think what they are learning is a valuable gift, not a tedious task ..."

Einstein's suggestions on what should be strengthened in fostering critical thinking for the younger generation today has always been emphasized by Professor. Klaus Schwab, Executive Director of the World Economic Forum (WEF). In his speech at the beginning of 2017, the scholar recommended: "We are at a turning point in history, always facing with economic, political, migration, terrorist and economic uncertainties, cracks in institutions, ethics, competence, leadership...", so any modern persons, no matter what profession they have, need training: $\mathrm{C}_{1}$ : Critical thinking competence, $\mathrm{C}_{2}$ : Creative competence, $\mathrm{C}_{3}$ : Communication competence, $\mathrm{C}_{4}$ : Collaboration competence

Talking about the true meanings of education, Nelson Mandela (1918 - 2013), the former president of South Africa and the 1993 Nobel Prize winner, reiterated that "Education is the most powerful weapon for changing the 
world. Education is the great engine of personal development." On his address at the Planetarium, Johannesburg, South Africa, 16 July 2003, he had such teachings:

"Education is the most powerful weapon for changing the world. Education is the great engine of personal development. It is through education that the daughter of a peasant can become a doctor, that the son of a mine worker can become the head of the mine that a child of farm workers can become the president of a great nation."

"Collapsing any Nation does not require use of Atomic bombs or the use of long range missiles. But it requires lowering the quality of Education and allowing cheating in the exams by the students.

The patient dies in the hands of the doctor who passed his exams through cheating.

And the buildings collapse in the hands of an engineer who passed his exams through cheating.

And the money is lost in the hands of an accountant who passed his exams through cheating.

And humanity dies in the hands of a religious scholar who passed his exams through cheating.

And justice is lost in the hands of a judge who passed his exams through cheating.

And ignorance is rampant in the minds of children who are under the care of a teacher who passed exams through cheating. The collapse of education is the collapse of the Nation."

At the latest time, Dalai Lama (1935) who is the world respectful man for being awarded with the Nobel Prize in 1989 for "advanced and constructive proposals" to solve the world conflicting issues. Regarding to happiness, he has an idea that "happiness is not available but is attained by our actions." He proposed twenty set of "2" for the youth's self-improvement and practice and he promoted four concepts on happiness, namely (i) the purpose of life is to seek happiness, (ii) happiness is determined more by one's state of mind than by external events, (iii) happiness can be reached by systematic mind practice and changes of attitude and points of view to life and (iv) the key to happiness is in our reach.

Finally, the matter of happy school in the modern time is concerned by Raja Roy Singh who proposed the perception on teacher - student relationship as that of friendship and morality. In his work "Education for the 21st century: Prospects of the Asia-Pacific" Raja Roy Singh has a profound point as follows:

"In the process of awareness - learner-centered learning, the teacher is not only the person who transmits discrete pieces of knowledge. Teachers help learners regularly stick with the larger structure. Teachers are also instructors, mentors, and role models of learners. Therefore, teachers are not specialized in a narrow discipline but are knowledge workers, lifelong learners. In perfecting the teaching process, teachers and learners are friends who work, study and explore together ... Aritostle referred to this relationship as "a kind of moral friendship" and Green-Thomas Aquinas called this kind of teaching "an act of love and compassion” ( pp. 115-116).

In a happy school, of course, learners must be happy. However, the learners are in a close relationship with the teachers, so when the learners are happy, the teachers must also be happy, then happiness is a complete one. Both students and teachers are happy when their relationships always reach noble values in their everyday living activities.

\subsection{Vietnam's Perspectives on Happy Schools}

The idea of building a school that teachers and students could be happy in their teaching and learning jobs is firstly mentioned by the Vietnam's outgoing president Ho Chi Minh. He has been recognized by UNESCO as "hero of national liberation" and "world's man of culture". Ho Chi Minh has the following profound recommendations for Vietnamese education. In his letter to students on the opening day of the first school year in the new era (September 1945), he had an earnest appeal: "Whether the Vietnamese country will become beautiful and whether the Vietnamese nation will be glorious and well-matched with the super powers in the five continents, mostly depends on your learning" (Ho, 2011). In 1947, in the book of "New Life", he discussed: "From elementary school, high school to university, they are all places for children and young people to train. Young people's brains are as pure as pieces of white silk. If we dye them green, they will be green. If we dye them red, they will be all red. Therefore, school learning has a great influence on the future of the young generation, and the future of the generation is the future of the country. Therefore, the most important thing to do is to teach students to love their homeland, to love the people. We must teach them to be independent, resilient, determined not to be inferior to anyone, determined not to be slaves" (Ho, 2011).

In his living time, Ho Chi Minh used to expected in the school that, there should be a relationship like "Teacher 
love students/Students respect teacher": that in discussing any affairs, students can express their ideas in a democracy manner, not in a win-win style; that the teacher must try to teach the student so that students can "understand quickly, remember longer, make rapid progress"; that the student are always "eager to study, eager to work, eager to make progress"; that "Teachers are diligent in teaching, students are diligent in learning".

The next person to propose the ideas of happy schools in Vietnam is Pham Van Dong (1906-2000). He was both an outstanding man of politics and culture and was also Ho Chi Minh's close comdre and excellent student. In the early 1980s, on his attendance to a meeting on education issue in Hanoi, Pham Van Dong directed the education service to implement the following principles "Schools must be as they are intentionally established, classes must be organized classes; teachers must do the jobs of teachers and students must do what students are supposed to do; teaching must be of that true kind of teaching and learning must be in right learning manner." Therefore, in order for a "happy school" to be formed as what he wished, the school's teaching staff must strive to reach the true extent of school's "spiritual structure" (teaching) and "material structure" (learning) and at the same time reach the "completion".

Following Pham Van Dong, Vo Nguyen Giap $(1911$ - 2011) was the next person to become concerned with the matter of building happy schools. Vo Nguyen Giap was a teacher of history, he became one of the world greatest military leaders. In a discussion on what should be done to implement the campaign of national education innovation by the $21^{\text {st }}$ century, Vo Nguyen Giap contributed the following profound ideas that anyone who has graduated from a training program (in a school) should have the below qualifications and qualities, including (i) deep understandings and sensitivity with the national cultural traditions, (ii) knowledge of modern science and technology and (iii) Independent capacity of thinking based on the combination of scientific thinking, systematic thinking and integrated thinking so as to live and perform activities flexibly, creatively in the complex world, which is full of changes and indefinities, and intermingled opportunities and challenges..."

After Vo Nguyen Giap, Nguyen Canh Toan (1926 - 2017) further deleloped the model of happy school. His proposed ideas on such schools became more realistic because he used to hold the positions of the Vice-Minister of Education and Training, the Rector of Hanoi National University of Education. In his dedicated letter to his colleagues and students, he stressed on a message "Never forget science of thinking in teaching." The ideas in his dedicated letter could be truly considered as vital foundations for the cause of building "happy schools" that is being implemented by the national education service. He reiterated that students could learn from the libraries and do their self-studies no matter how teaching and learning technologies have developed. He also highlighted that the learning environments at schools and with friends were of the same significant importance. He expected that schools should shift the training model of "2-4-8" to that of "2-5-10". He pointed out that: "2-4-8" training model means that all teaching and learning activities are within the coverage of the 2 textbook pages, 4 walls of the classroom and 8 hours of "bureaucratic work", while "2-5-10" training model covers the 2 directions of teacher-student interaction, 05 learning situations and 10 kinds of thinking for the graduated students.

"2" means the two main teaching- learning doers with the teacher being an academic advisor and the students being knowledge explorer while " 5 " means that teacher - students will create 5 learning situations: (i) du nhi tri learning by playing and playing for learning, (ii) lễ nhi tri - first learning how to behave and then learning knowledge, (iii) tự nhi tri - learning in combination with thinking drill, (iv) hành nhi tri - learning in association with practice, and (v) khốn nhi tri - learning from challenges.

"10": Students should practice 10 kinds of thinking, including spatial, logical, dialectical, linguistic, algorithm, scientific and experimental, technological, economic, political and managerial thinking.

In a close relation to Nguyen Canh Toan's thoughts, Nguyen Khac Vien (1913 - 1997) was appraised by educationists for his proposed ideas on very impressive model of "teaching toward students' personality development. On his talk to schools after the country's unification, he used to emphasize three points regarding to students' personality development.

"T1": Building a firm personal social status without depending on others.

"T2": Cherishing a tremendous source of human love, first with family members, then with siblings and relatives, and with those in the nation.

"T3": Building up a stable mind, take the ownership of yourself and keep your mind steady despite adversities.

Nguyen Khac Vien was appraised for proposing an impressive paradigm of a school model that is believed to help develop students' personalities.

(a) He believed that everybody, right at the birth time, owns his personalities $\left(\mathrm{A}_{0}\right)$ which include existence, heart and destiny (of social origin) 
$\mathrm{F}\left(\mathrm{A}_{0}\right)=\mathrm{f}($ existence, heart, destiny $)$

When a person begins his contact with the real world, he starts to sense the world around. And from this early phase, a person's personalities will, through teaching and learning process, develop into two ways:

$$
\begin{gathered}
\text { Sensation } \rightarrow \text { Perception } \rightarrow \text { Knowledge } \\
\text { Emotion } \rightarrow \text { Affection } \rightarrow \text { Gratitude }
\end{gathered}
$$

The first way of personality development will form IQ (Intelligence Quotation) while the second way of personality development will form EQ (Emotion Quotation)

(b) It is by the converge of knowledge and gratitude that a person knows how to behave and develop his personalities $\left(\mathrm{A}_{1}\right)$.

(c) In order for $A_{1}>A_{0}$ and $A_{n}>A_{n-1}$ a person must do three following things synchronously:

"Existence": positive living must be implemented

"Heart": frequent self-improvement is done

"Destiny": right behavior (modesty - respect - politeness - gratitude) must be ensured).

$$
F\left(A_{1}\right)=f \text { (nourishing, self-improving, behaving) }
$$

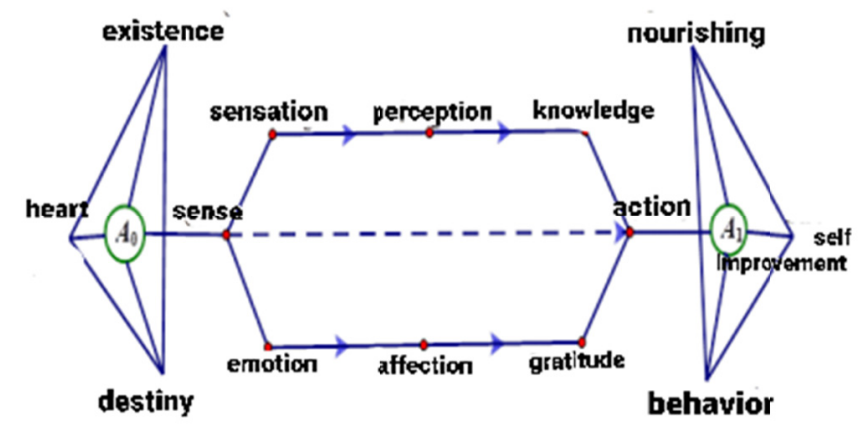

Figure 1. Paradigm of teaching by Nguyen Khac Vien $\left(A_{1}>A_{0} ; A_{n}>A_{n-1}\right)$

In summary, from the above-mentioned contents which cover the proposals, ideas, thoughts by key educators, ideologists, leaders, managers in the world and in Vietnam, we realize that each person has his own concepts with different aspects of happiness, happy schools as well as models and diversified solutions to create a happy school. However, they all share the common features of identifying goals of school education; the qualities and capacities of learners; methods and forms of attraction, persuasion, guidance, inspiration in teaching activites; teacher-student relations in teaching; the quality of education, the teaching environment, the safety and love in teaching, the constructs of the teaching situations and finally the behaviors that must be criticized and condemned in schools such as offense, violence, bullying,... in school. Consequently, in order to have further background for the research problem of happy schools, in addition to the summarized contents above, we conducted a survey on happy schools, mainly the concepts of what a happy school is, the needed and systematic solutions of building happy schools, the results of which will be presented below.

\section{Findings and Discussions}

\subsection{Findings from the Interviews}

On studying the theories and perspectives on happiness, happy schools, the authors interviewed 168 participants, including 08 educational managers, 15 teachers, 95 students (elementary, junior and senior high school) and 50 university students. The interview questionnaires used during the interview process were around perceptions, understanding of happiness, happy schools, componential elements of happy schools, criteria for happy schools and solutions to building happy schools... Findings from the interview's responses show that:

(i) The concept of happiness $(n=154)$ is a person's emotional state when a certain need is satisfied; is a state of joy because the wish and desire are completely obtained; is a feeling of bliss, peace of mind and contentment with a long life 
(ii) A happy school $(n=155)$ is a place where teachers, parents and students all feel happy, each learner feels the safety, friendliness, and love that spreads from teachers, friends with their joy beng multiplied and sadness being shared; a place where there is no imposition, stereotypes, unilateral decisions, and violence.

(iii) The model "Happy School" $(\mathrm{n}=149)$ comprises of the basic factors as Human, System and Environment.

(iv) The fundamental criteria for building a happy school $(\mathrm{n}=142)$ are love and share; safety and respect

(v) The purpose of building a happy school is to $(n=150)$ : Help students have the best learning environment; create students' eagerness in learning; enable students to be more motivated, proactive and positive, and to continuously create new values; Help teachers to be more motivated to teach and create new teaching techniques for students to be more interested in the lessons

(vi) Happy learning environment includes the basic elements $(n=145)$ : respect for the development of each individual; teachers' freedom for creativeness, for their teaching method innovation; good practice of democracy (encouraging the questioning, exchanging, discussing and debating activities).

(vii) Specific measures for a happy school

- The school should organize talks with students, create forums for them to communicate, boldly exchange their thoughts, aspirations, and give their suggestions and recommendations $(n=145)$

- The school must regularly organize meetings with students and parents to promptly grasp their circumstances and aspiration to coordinate with their families in educating students $(n=125)$.

- The teachers must love and take responsibility for students' studies, know how to connect students and build a class whose members unite, care, love, share, and help each other (n-148).

- The school should encourage students to plan and take good care of trees, create more green spaces in classrooms, schools, and keep a green - clean - beautiful - safe learning environment $(n=120)$.

- The school should regularly organize thematic meetings on teachers' ethics, continuously and effectively implement the launch: "Every teacher is an example of good morality, self-study and creativeness", "Build building school with standardized culture - model teachers - elegant students" (n-135).

- The school should organize more clubs and activities for students to experience and interact, of which activities with parents' participation should be increased (n-148).

The perspective of happiness is the feeling of satisfying stage, with the needs being met, and is the joy and the safety in life. First, a happy school is a place where teachers and students feel comfortable, peaceful, safe in teaching and training ... Impositions, bullies, rude behavior, physical abuse, and honor infringement are all manifestations of unhappiness. The learners should be central factor in all school's activities. Second, school is a structured system with many factors but mainly by 3 factors: people, teaching process and the environment. Third, there are many specific criteria to evaluate whether a school is happy, but the main ones are love, safety, respect and quality, depending on the degree of rank in the criteria of love, safety and respect. Fourth, a happy school must be built towards promoting the creativity and potentialities of each person, including teachers and learners, contributing to creating a foundation for society's development. Finally, to build a happy school, there are many proposed measures relating to people factors, teaching process, teaching environment, including facilities, teaching equipment, trees, landscape, attention to the management factor, democracy implementation and practice, enhancement of individual initiatives, and each person's talents and potentialities.

From the theoretical studies, the perspectives on building schools towards happiness, the happy schools by researchers, scholars and the survey results for happy schools, we have identified the needed elements and made recommendations on building happy schools.

4.2 Realizing the Wisdom of Educators on the Matter of "Organization-Pedagogy" for a "Happy School" and Roadmap to Sustainably Develop a Model of Future Happy Schools in Vietnam

4.2.1 Building a Happy School Must Base on Identifying the School's Typical Factors

- $\quad$ Purpose of education (P)

- $\quad$ Contents of education (C)

- $\quad$ Methods of education (M)

- $\quad$ Educators (T)

- $\quad$ Subject of education (S) 
- $\quad$ Form of education (F)

- Conditions of education (Cd)

- $\quad$ Education environment (E)

- Mechanics of education management (Ms)

- $\quad$ Regulations (R)

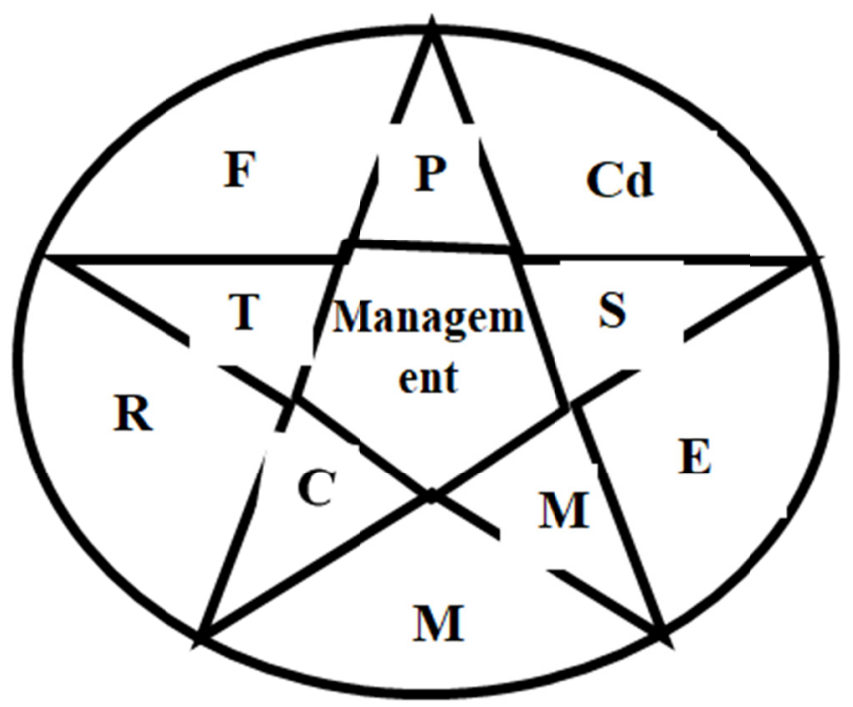

Figure 2. Componential elements

The above 10 elements can be arranged into a star shape with the control button in the center of the star. Good management of the factors makes them operate normally and creates the integral development of the teaching process. Most of the above factors are those belonging to the educational program (including P, C, M, F, Cd, R, Ms), which contribute to the quality of education. Therefore, the significant matter of building a happy school is building the educational program. The problem is what and how to teach? Recently, there are many studies that need to introduce MINDFULNESS into teaching program in schools (Srinivasan, 2020).

\subsubsection{Identifying the Factors and Criteria for a Happy School}

Conducting studies on happy schools, we believe that there are three main factors that create a happy school: people, working environment and working style. Thus, a happy school is an organization that has a good people people relationship (it is the relationship between teachers and students, managers with teachers, staff and students ...); working, living, learning and research conditions of school managers, teachers, assistant staff, students, and their working style and manner. Considering the above factors, we found that with 3 core criteria to care about, namely love, safety and respect, thus by good implementation of these 3 criteria, each involved person will automatically find their happiness. This should be fully shown in the school so that happiness in school, in the classrooms not only the learners, the teachers but the outsiders feel happy.

The first is love. A happy school is a place where teachers, parents and students all feel happy. It is a living environment with a nice and friendly relationship. In that relationship, from time to time, depending on the place, each person can be each other's teachers, students. It shows a high sense of responsibility between people living, learning and exchanging with each other. Every school day is a happy day.

The second is safety. A happy school is a place where there is no violence and there is no invasion on the living and learning environment. Teaching activities are guaranteed with security and safe conditions, not threatened by acts of abuse, extremism or violence; people's spirit not being intimidated. All the bruises, bullies, the shortage of fairness and democracy will not exist.

The third is respect. A school is considered to be happy when there are no violations to the morality and dignity of teachers and students. However, there is respect for differences in addition to perceptions and activities for the common goal of the community or society development. Personal feelings are respected and appreciated, without any imposition, imperativeness, stereotypes, and mechanical solution of problems. 


\subsubsection{An Awareness of the Headmaster's Important Roles in Building a Happy School}

Building a happy school is both the goal and the value of advanced education. In the school, the headmaster with the position of "captain" plays an important role in building and operating the "ship" of happiness. Accordingly, to build a happy school, first of all, the headmaster must be a happy person, a solid "happy fulcrum" of colleagues and students. Second, as a leader, the headmaster must build a team of happy teachers, so that each teacher is a "happy ambassador" in school and in life. Third, the headmaster is supposed to inspire the whole school to desire and pursue the mission of building a "school culture" - a fundamental element of building a happy school. Fourth, the headmaster should build the "rules of happiness" that are not only expressed by written rules, regulations and procedures, but more importantly, such those "conventions of the hidden educational programs" will be implicitly and happily understood as a matter of course. Fifth, the headmaster should invest in building "happy spaces" referring to both physical and non-physical in schools. Finally, as a "special teacher", principals should wholeheartedly connect with parents and regularly share the values of a happy school with students, persistently pursue the role of spreading positive energy of happiness.

\subsubsection{A Proposed Set of Mark-Ten Massages of a Happy School}

From the perspectives of world researchers, UNSECO's criteria and the practice of building a happy school in Vietnam, the study authors propose ten points of a school striving to build a happy school.

(i) We (the school's pedagogical collective) are happy when the students are happy.

(ii) The learners (students) are important subjects of the school, considered as the blood of the school, and are the decisive factor for the school's survival.

(iii) Students and teachers cooperate with each other. In the school, there is no empowering pedagogy but only the pedagogy on the spirit of discipline - tolerance - responsibility - creativity and interaction:

(iv) The students entering the school are the benefactors of the school. During the teaching process, the school does not think that they have blessed them, but the students have blessed the school because there is a new ethnology transferred, the school's mission is realized.

(v) The work of the school is only successful when students are not outside the purpose of education. The school encourages students to "Turn the educational process into a process of self-education".

(vi) All members of the school always tell themselves: "Students are not factors for the school to train them".

(vii) Students are not just meaningful in statistics: they are the ones who crave for the knowledge and skills that the school has the duty to lead them to dominate.

(viii) Students set their expectations from school in term of their personality development, and it is the school's mission is to help them fulfill their aspirations.

(ix) Students must be treated with care when attending school, able to enjoy the best services that the school can exploit in partnership with the community.

(x) The school strives to be the forehead that leads the wisdom of the community (according to the pedagogical function assigned by the society), which is also the heart blending the community's humanity.

\section{Conclusion}

Conducting research toward building a school which is a safe, healthy and developing place for each member of the school and is a place to build up and give support to the community members, the society to their higher and further growth, to the students to their personality perfection are the wishes and efforts of researchers, leaders, managers and each person and are of practical demand at the quite early age in the society's development process.

The article has outlined the development process of the desired schools. The concept of a happy school has been introduced by UNESCO in recent years while this has also been launched by Vietnam's Ministry of Education and Training in the education sector with active response by educational researchers. The reality has showed that, "happy schools" have actually been mentioned by leaders and researchers in different aspects of the educational development process. The goal is to build a friendly, safe and open learning environment in which students feel that going to school is a happy thing, teachers will do so when teaching, and their happiness is not only present at school but also spreads to families. When people feel happy, they can feel free to create, dedicate, and build up new things in studies as well as in work.

Basing on the contents, the development model towards a happy school, the authors also mentioned the school's required factors, of which become the essential criteria of a happy school with the role of the headmaster being 
very important to building happy schools and the authors have also introduced the distinct messages that a happy school should spread. In such circumstance, the headmaster as the central figure, who is in charge of the school's leadership and management, is of especially significant importance.

\section{References}

Crip, R. (2000). Aristotle: Nicomacchean Ethics. Cambridge University Press.

Do, T. D. (2019). Building a Happy School. Education and Times. Retrieved from https://giaoducthoidai.vn/de-xay-dung-truong-hoc-hanh-phuc-3830008.html

Goksoy, S. (2017). Situationsthat Make Students Happy and Unhappy in Schools. Universal Journal of Educational Research, 5(12A), 77-83. https://doi.org/10.13189/ujer.2017.051312

Ho, C. M. (2011). Ho Chi Minh complete volume series (Vol. 4). National Political Publishing House.

Ho, C. M. (2011). Ho Chi Minh complete volume series (Vol. 5). National Political Publishing House.

Nguyen, N. (2019). Happy School: Principal's Impedance and Motivation. Retrieved from http://congdoangdvn.org.vn/index.aspx?def $=556 \& \mathrm{ID}=4638 \&$ CateID $=535$

Nguyen, T. B. (2016). Value system-The goal of developing Vietnamese learners' personality. Vietnam Education Publishing House, Hanoi.

Osho. (2019). Happiness is at our heart. Hong Duc Publishing House, Hanoi.

Pham, M. G., \& Dang, Q. B. (2021). The competences of teaching staff and principals in the context of educational innovation and school development. International Education Studies, 14(1), 65-75. https://doi.org/10.5539/ies.v14n1p65

Pham, T. P. T., \& Bui, T. N. (2020). Solutions to building a happy school, reducing learning pressure for students at Nguyen Binh Khiem High School - Hanoi. Vietnam Education Science Journal.

Singh, R. R. (1994). Education for the 21st century: Prospects of Asia - Pacific. Vietnam Institute of Educational Science Publisher.

Srinivasan, M. (2020). Happy class. Hanoi Publishing House

Talebzadeh, F., \& Samkan, M. (2011). Happiness for our kids in schools: A conceptual model. Procedia - Social and Behavioral Sciences, 29, 1462-1471. https://doi.org/10.1016/j.sbspro.2011.11.386

UNESCO Bangkok office. (2016). Happy school: A framework for learner well-being in the Asia-Pacific. Retrieved from http://creativecommo.org/licenses/by-sa/3.0/igo/

Vu, J. (2016). Education in the age of knowledge. Labor Publishing House, Hanoi.

\section{Copyrights}

Copyright for this article is retained by the author(s), with first publication rights granted to the journal.

This is an open-access article distributed under the terms and conditions of the Creative Commons Attribution license (http://creativecommons.org/licenses/by/4.0/). 